\title{
Evaluation of Dentistry Students' Lifelong Learning Tendencies During the COVID-19 Pandemic
}

\author{
Duru Aras-Tosun ${ }^{1, *}$ and Burcu Küçük-Biçer ${ }^{2}$

\begin{abstract}
${ }^{1}$ Ankara University, Faculty of Dentistry, Department of Basic Medical Sciences, Ankara, Turkey and ${ }^{2}$ Gazi University, Faculty of Medicine, Department of Basic Medical Sciences, Department of Medical Education and Informatics, Ankara, Turkey

*Corresponding Author; duruaras@gmail.com
\end{abstract}

\begin{abstract}
Purpose: Dentistry education is a life-long, continuous education. The aim of this study was to determine the lifelong learning (LLL) tendencies of the dental faculty students who were receiving distance education during the Covid-19 pandemic.

Methods: Two hundred fifty-eight dentistry students participated the study. Research data was collected by 'Lifelong Learning Disposition Scale' (LDS). In the first part of the questionnaire, students were asked to reply socio-demographic questions and their ability to learn during the distance education process of the COVID-19 pandemic. In the second part, there were questions about LLL. The low score obtained from the scale indicates that the LLL tendency is high. ANOVA and t-test were used for analysis of LDS score, and the Mann Whitney-U and Kruskal Wallis tests were used for sub-dimensions.

Results: During the COVID-19 Pandemic, $40.3 \%$ of the students stated their status of learning skills as medium, $28.7 \%$ as bad and $11.6 \%$ as very bad. Students' mean score on the LDS scale was $88.26 \pm 9.8$. The mean LDS score was statistically significant according to their class, gender and their assessment of learning skills during the COVID-19 pandemic $(p<0.05)$. There was no correlation between the monthly income and academic success levels of the students and their LDS scores ( $p>0.05)$.

Conclusion: In this study, it was determined that the students made their own evaluations correctly during the Covid-19 pandemic. LDS scores of the students who stated their learning status as bad were significantly higher by 1,187 times. During the Covid-19 pandemic, it is important to communicate using educational methods that aim to support students' learning skills. Therefore, new interventions should be planned to increase students' LLL tendencies.
\end{abstract}

Key words: Covid-19 pandemic; dentistry education; distance learning; lifelong learning

\section{Introduction}

In addition to what is learned in daily life, the information obtained from formal and non-formal institutions of education is also a part of the life of the individual. "Life-Long Learning" (LLL) is a process that includes all learning activities for the acquisition and development of all kinds of knowledge, skills and abilities. This process is geared towards meeting the needs of students to do better both at university and throughout their lives. Therefore, the concept of LLL is a process that starts from preschool period throughout the entire education life that continues in sociocultural and educational areas at home, business life and in the society. ${ }^{1}$

Basic knowledge and skills related to LLL are acquired in childhood and continue throughout the life of individual. The learning method requires the student to choose the one that suits his / her needs with his / her own effort. Professional LLL defines the inter- ests and needs of individuals and development of their competencies that are appropriate for their learning areas. ${ }^{2}$

Dentistry education is a life-long, continuous education. It is known that in the Covid-19 period, distance education process has different effects than face-to-face education. ${ }^{3}$ The aim of this study was to evaluate professional LLL tendencies of dentistry students during the distance education process of the COVID-19 pandemic by "Lifelong Learning Disposition Scale" (LDS) developed by Coşkun et al. 4

\section{Methods}

Ethical approval \& study design

Two hundred fifty-eight students from Ankara University Faculty of Dentistry participated the study with the permission of the Local 
Ethics Committee. Before fulfilling the disposition, students were asked to give their consents.

\section{Features of the scale}

Research data were collected by LDS, a 6-point Likert-type scale consisting of a total of 25 items and four sub-dimensions. ${ }^{4}$ Psychometric properties of the LDS show that the scale is valid and reliable. ${ }^{5}$ In the first part of the questionnaire, socio-demographic variables (term, gender, monthly income and course success) and the status of learning skills during the COVID-19 pandemic were asked. In the second part, there are questions related to the LLL. The first dimension of the scale is motivation ( 4 items), the second dimension is persistence ( 8 items), the third dimension is lack of regulation in learning ( 5 items), and the fourth dimension is lack of curiosity ( 8 items). The minimum score that can be obtained from the scale is 25 and the maximum score is 150 . The low score obtained from the scale indicates that the LLL tendency is high. This scale can be used in studies aiming to determine the LLL tendencies of individuals who continue their pre-graduation education or in health services, to reveal the factors that affect these trends, and to monitor LLL activities. ${ }^{1}$

\section{Statistical analysis}

ANOVA and student's t-test were used for the score of the LDS scale, and the Mann Whitney-U and Kruskal Wallis tests were used for sub-dimensions. Linear regression method was used to determine the variables affecting the LDS score. The relationship between the LDS score (the dependent variable) and the independent variables of term, gender, course success, monthly income and learning skills during the Covid-19 pandemic was investigated.

\section{Results}

Forty-six-point-nine percent of the students (121) were semester 1 students, while $65.1 \%$ (168) were female. $67.8 \%$ of the participants in the study stated their monthly income as medium level, as well as academic success by $53.5 \%$.

During the COVID-19 pandemic, $40.3 \%, 28.7 \%$ and $11.6 \%$ of the students stated the status of their learning skills as medium, bad and very bad, respectively. The mean score of the student's LDS was $88.26 \pm 9.8$. The mean LDS score was statistically significant when their semester, gender and the assessment of their learning skills in COVID-19 pandemic were considered $(p<0.05)$. There was no correlation between the LDS scores and the monthly income of the students, as well as their academic success $(p>0.05)$. The significance of the scores of the students' LLL tendencies scale and its sub-dimensions according to socio-demographic variables is given in Table 1. LLL trend score was found to be the highest in semester 1 students, and it was found to be significantly higher in female students and students who stated that their learning skills as very bad during the COVID-19 pandemic compared to other students.

When the sub-dimensions were examined, the motivation subdimension was affected by course success and the status of learning skills during the COVID-19 pandemic, while the persistence subdimension was affected by academic achievement and the status of learning skills during the COVID-19 pandemic. It was determined that the lack of curiosity sub-dimension was affected by gender in regulating learning, and the lack of curiosity was statistically significantly affected by term, gender and course success (Table 1 , $\mathrm{p}<0.05$ ).

As a result of the linear regression analysis, it was determined that the variables of gender $(\mathrm{p}<0.001)$ and the status of learning skills during the COVID-19 pandemic $(\mathrm{p}=0.045)$ affect the LDS score.

\section{Discussion}

It is expected that dentists will make the necessary effort to meet the increasing expectations of the society during the Covid-19 pandemic. For this reason, students of the faculty of dentistry should follow the innovations in science and technology and adopt the philosophy of LLL to meet the demands expected in their professional lives. In this study conducted to examine the LLL tendencies of the students studying at the dentistry faculty, it was determined that the LDS score of the students were at a medium-low level (88.26 \pm 9.8). When the sub-dimension averages of the LDS were examined, the high average of the sub-dimensions of motivation, persistence, deprivation in organizing learning and lack of curiosity also supported the finding that students' LLL tendencies were low. Karaduman and Tarhan, ${ }^{6}$ examined the relationship between university students' LLL tendencies and their self-efficacy perceptions and reported that the students' LLL tendencies were high. Dikmen et al, ${ }^{7}$ concluded that the LLL competencies of the students are at a good level in his study investigating the LLL competencies of medical faculty students. In other studies, conducted on different sample groups, it was found that individuals' LLL tendencies were high. ${ }^{8}$ Therefore, in this study, it can be said that the LLL tendencies of the students studying at the dentistry faculty are medium-low, and their willingness and motivation to participate in activities related to LLL is not very high. In our study, it was determined that male students' 'LLL tendencies are higher than female students' LLL tendencies. In addition, it was determined that mean scores of students' deprivation and curiosity sub-dimension significantly differ according to gender. Similar to our study, Dikmen et al ${ }^{7}$ examined the LLL tendencies of medical faculty students, and it was found that the LLL tendencies of male students were higher. According to these results, it can be said that male students are more motivated in LLL and investing in their personal development. However, other studies have revealed different findings between LLL tendency and gender variable. Although there are studies that stated that LLL tendencies are higher than male students than females, performing these studies in non-health areas prevents the generalization of the results. ${ }^{6,9}$

Reading habit is an important factor that positively affect the LLL competence. ${ }^{10}$ In the literature on book reading habits, individuals should gain the habit of regular reading at an early age in order to gain LLL competence. In this study, a significant difference was found between the grade of students and their LLL tendencies. It was determined that the total scores of the third- and fourth-year dentistry students regarding LLL were significantly higher than the first- and second-year students. Similarly, Dikmen et al ${ }^{7}$ reported that LLL tendencies of senior medical faculty students were higher than the first-grade students. According to these results, it is seen that as the grade level of students increases, their LLL tendencies also increase. Therefore, it is seen that students are in a LLL desire and effort. However, in this study, no significant relationship was found between students' economic status, school success and LLL tendencies.

It was observed that the evaluation of the learning status of the dentistry students during the Covid-19 process significantly affected the LLL score. Students who defined their learning status as bad were also found to have high LLL scores. It can be said that there are students who negatively developed their perceptions of LLL during the pandemic process. Therefore, in future studies, there is a need to examine LLL tendency outside the pandemic period with larger samples.

\section{Conclusion}

While the minimum score that students can get from the scale is 25 and the maximum score is 150 , the minimum score that the students get out of LDS was 51 and the maximum was 123. The 
Table 1. Significance of the scores obtained by the students from the LDS and its sub-dimensions according to some socio-demographic variables (N = 258)

\begin{tabular}{|c|c|c|c|c|c|}
\hline LDS vs. Socio-Demographic Measures & Semester & Gender & Monthly Income & Course Success & $\begin{array}{l}\text { Learning Skills During the } \\
\text { COVID-19 Pandemic }\end{array}$ \\
\hline Lifelong Learning Tendency & 0.001 & $<0.001$ & 0.552 & 0.338 & 0.049 \\
\hline Motivation (4 questions) & 0.181 & 0.191 & 0.161 & 0.001 & 0.004 \\
\hline Persistence (8 questions) & 0.029 & 1.305 & 0.333 & $<0.001$ & 0.012 \\
\hline Lack of Regulation of Learning ( 5 questions) & 0.198 & $<0.001$ & 0.217 & 0.188 & 0.723 \\
\hline Lack of Curiosity (8 questions) & 0.030 & $<0.001$ & 0.137 & $<0.001$ & 0.262 \\
\hline
\end{tabular}

average score of the students was 88.3. The high scores of the scale indicated that the students did not develop their learning skills sufficiently, and their undergraduate education should be reviewed in this regard.

In this study, it was determined that the students made their own evaluations correctly during the Covid-19 pandemic process. The LLL tendency score of the students who stated their learning status as bad was found to be 1.187 times higher, which was statistically significant. In the Covid-19 pandemic, it is important to communicate by using educational methods that aim to support students' learning skills. New interventions should be planned to increase students' LLL tendencies.

The life skills scale score of female students was five times higher than male students. It should be aimed to reveal the reasons for this difference with qualitative research, especially in the subdimensions of regulation of learning and lack of curiosity, and to eliminate the shortcomings of female students.

Low course success correlated with the LDS score. Students who have problems in motivation and persistence dimensions also had low academic success. In the Covid-19 period, ensuring the interaction of the students with the faculty and asking them to participate in applications such as zoom will increase motivation.

Students in the lower semester have higher LLL scores. These students spent all or most of their post-secondary education in distance education and could not interact with the school. Another situation is that the lower years of high school education experienced exam stress and had to work for a long time. The desire to take a break in the first years of the faculty may have caused them to get high scores in the persistence sub-dimension. To encourage these students to spend more time in face-to-face trainings at the faculty in the post-Covid-19 period will help to eliminate the shortcomings that this process will create.

\section{Author Contributions}

All authors have contributed to; conception and design of the study, data collection and analysis, writing the manuscript, approval of the final version to be submitted.

\section{Conflict of Interest}

Authors declare that they have no conflict of interest.

\section{Authors' ORCID(s)}

D.A.T. $\quad 0000-0001-8236-4315$

B.K.B. 0000-0002-5615-264X

\section{References}

1. Akkuş N. Yaşam boyu öğrenme becerilerinin göstergesi olarak 2006 PISA sonuçlarının Türkiye açısından değerlendirilmesi. Yayınlanmamış Yüksek Lisans Tezi, Hacettepe Üniversitesi Sosyal Bilimler Enstitüsü, Ankara. 2008.

2. Havva K. Küreselleşme sürecinde yaşam boyu öğrenme ve yetişkin eğitimi gerçeği. Akademik İncelemeler Dergisi. 2014;9(2):91-111.

3. Adnan M, Anwar K. Online Learning amid the COVID19 Pandemic: Students' Perspectives. Online Submission. 2020;2(1):45-51.

4. Coşkun YD. Üniversite Öğrencilerinin Yaşam Boyu Öğrenme Eğilimlerinin Bazı Değişkenler Açısından İncelenmesi [Thesis]; 2009.

5. Arslan SF, Sarikaya O, Vatansever K. Yaşam boyu öğrenme eğilimi ölçeğinin tıp eğitimi alanı için geçerlik ve güvenirlik çalışması. Tıp Eğitimi Dünyası. 2016;15(47).

6. Karaduman A, Tarhan S. Examining the relationship between university students' lifelong learning tendencies and their self-efficacy perceptions Üniversite öğrencilerinin yaşam boyu öğrenme eğilimleri ile özyeterlik algıları arasındaki ilişkinin belirlenmesi. Journal Of Human Sciences. 2017;14(1):355-375.

7. Dikmen Y, Uslu Yuvacı H, Erol F. The investigation of lifelong learning tendencies in medical faculty students. Journal of Human Sciences. 2017;14(3):2399-2408.

8. Günüç S, Odabaşı HF, Kuzu A. Yaşam Boyu Öğrenmeyi Etkileyen Faktörler. Gaziantep University Journal of Social Sciences. 2012;11(2).

9. Kılıc C. Öğretmen adaylarının yaşam boyu öğrenmeye yönelik algıları. Eğitim ve Öğretim Araştırmaları Dergisi. 2014;3(4):7987.

10. Odabaş $\mathrm{H}$, Odabaş $\mathrm{ZY}$, Polat C. Üniversite öğrencilerinin okuma alışkanlığı: Ankara Üniversitesi örneği. Bilgi Dünyası. 2008;9(2):431-465. 